\title{
FIDUCIARY DOCTRINE: A CONCEPT IN NEED OF UNDERSTANDING
}

\section{LEONARD I. ROTMAN ${ }^{\circ}$}

The author suggests that one of the primary problems plaguing the application of fiduciary doctrine in contemporary jurisprudence is the failure to appreciate its contextual nature and underlying purpose. The acontextual analysis and rigid application of standard formulae by the judiciary is harmful to the understanding of fiduciary doctrine, which requires that due attention be paid to the unique requirements of particular relationships. The history of fiduciary jurisprudence reveals that more confusion than knowledge currently exists in this area of the law. What is needed is a return to the fundamental elements of fiduciary doctrine so that its more precise application in accordance with its underlying purpose and situation-specific nature becomes possible.
L'auleur suggère que dans la jurisprudence contemporaine, l'un des principaux problèmes propres à l'application de la doctrine fiduciaire provient d'un manque d'appréciation de sa nature contextuelle et de son objet sous-jacent. Toute analyse acontextuelle et application rigide d'une formule standard par l'ordre judiciaire nuit à la compréhension de la doctrine fiduciaire qui requiert que soit pris en compte les conditions uniques des relations particulières. L'histoire de la jurisprudence fiduciaire révèle que dans ce domaine du droit, la confusion règne plus que le savoir. II próne un retour aux élements fondamentaux de la doctrine fiduciaire, qui permettra une application plus précise, conforme à son objet profond et à la nature particulière de chaque situation.

\section{TABLE OF CONTENTS}

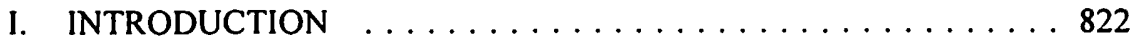

II. A FUNCTIONAL APPROACH TO

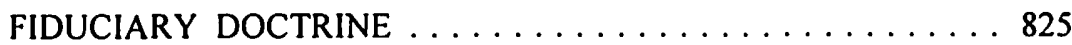

A. THE SITUATION-SPECIFIC NATURE OF

FIDUCIARY DOCTRINE . . . . . . . . . . . . . . . 829

B. THE CATEGORICAL OPEN-ENDEDNESS

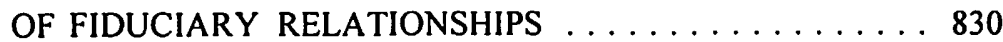

III. IMPLEMENTING THE FUNCTIONAL APPROACH $\ldots \ldots \ldots 832$

IV. THE MISAPPLICATION OF

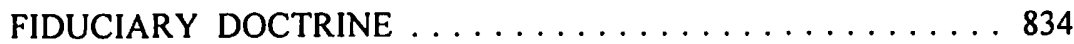

V. FIDUCIARY THEORIES $\ldots \ldots \ldots \ldots \ldots \ldots \ldots \ldots \ldots . \ldots \ldots 37$

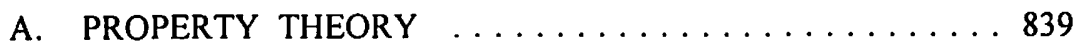

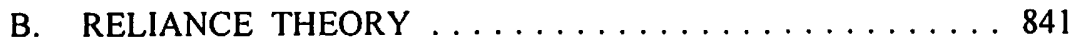

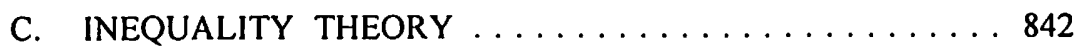

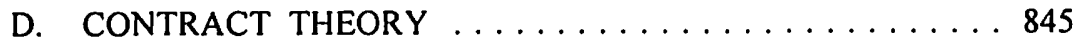

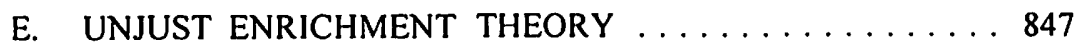

F. UTILITY THEORY . . . . . . . . . . . . . . . . 849

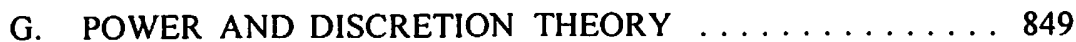

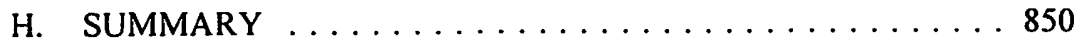

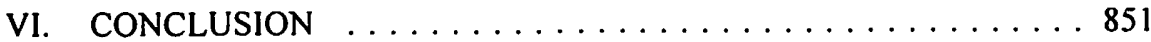

Faculty of Law, University of Alberta. I wish to thank Tammy Dwosh and Jim Phillips for their helpful comments and suggestions on earlier drafts of this article. 


\section{INTRODUCTION}

Fiduciary doctrine is an elusive concept. It has a lengthy existence, dating back over 250 years in English law to the celebrated case of Keech v. Sandford.' Before that, it had been a well-established part of Roman law. ${ }^{2}$ The duration and frequency of fiduciary law's application to a wide variety of relationships fosters the impression that the fiduciary concept is one of the most well-understood of legal doctrines. Indeed, within the past thirty years or so, the Supreme Court of Canada has discussed the existence of fiduciary relationships between senior officers/directors and a corporation, ${ }^{3}$ custodial parent and non-custodial parent, ${ }^{4}$ solicitor and client, ${ }^{5}$ federal government and Indian band, ${ }^{6}$ doctor and patient, ${ }^{7}$ father and daughter, ${ }^{8}$ and financial advisor and client. ${ }^{9}$ Upon closer scrutiny, however, the frequent judicial application of fiduciary principles is only a thin veneer concealing the uncertainty which plagues fiduciary theory. ${ }^{10}$

The law reports abound with descriptions of relationships as fiduciary when they actually bear little or no resemblance to such relationships. "In fact, the judiciary has

(1726), 25 E.R. 223 (Ch.).

Certain relations in Roman society - such as those of husband and wife, physician and patient, guardian and ward - had fiduciary-type rules imposed upon them to regulate their interaction. Other fiduciary-like relationships were also regulated. For example, tutors could not transact with their pupils where a question was raised as to profit accruing to the tutors or their families (unless such a transaction was done without risk and by public auction). In the absence of such a scenario, transactions between tutors and pupils were valid only where the consent of a co-tutor or curatornamed "ad hoc"' was obtained. See E. Vinter, $A$ Treatise on the History and Law of Fiduciary Relationships and Resulting Trusts (Cambridge: W. Heffer \& Sons, 1955) at 3. Canadian Aero Service Lid. v. O'Malley (1973), 40 D.L.R. (3d) 371 (S.C.C.) [hereinafter Canadian Aero Service].

Frame v. Smith (1987), 42 D.L.R. (4th) 81 (S.C.C.). While the majority in Frame did not find a fiduciary relationship to exist, Wilson $\mathrm{J}$. in dissent held otherwise. Canson Enterprises Lid. v. Boughton \& Co. (1991), 85 D.L.R. (4th) 129 (S.C.C.).

Guerin v. R. (1984), 13 D.L.R. (4th) 321 (S.C.C.) [hereinafter Guerin].

McInerney v. MacDonald (1992), 93 D.L.R. (4th) 415 (S.C.C.); Norberg v. Wynrib (1992), 92 D.L.R. (4th) 449 (S.C.C.).

M.(K.) v. M.(H.) (1992), 96 D.L.R. (4th) 289 (S.C.C.).

Hodgkinson v. Simms (1994), 117 D.L.R. (4th) 161 (S.C.C.) [hereinafter Hodgkinson].

Sce P.D. Finn, "The Fiduciary Principle" in T.G. Youdan, ed., Equity. Fiduciaries and Trusts (Toronto: Carswell, 1989) at 24: "It is striking that a principle so long standing and so widely accepted should be the subject of the uncertainty that now prevails"; R. Cooter \& B.J. Freedman, "The Fiduciary Relationship: Its Economic Character and Legal Consequences" (1991) 66 N.Y.U. L. Rev. 1045 at 1045-46: "Legal theorists and practitioners have failed to define precisely when such a relationship exists, exactly what constitutes a violation of this relationship, and the legal consequences generated by such a violation"; P.D. Maddaugh, "Definition of Fiduciary Duty" in Fiduciary Duties, Law Society of Upper Canada Special Lectures, 1990 (Toronto: De Boo, 1991) [hereinafter Fiduciary Duties] at 16: "Who is a fiduciary? The answer to this question, despite hundreds of years of litigation on the subject, is not at all clear. The term 'fiduciary' is not one used by ordinary people. It is only used by lawyers. This in itself should arouse our suspicions." Two of the most notorious examples of the misapplication of fiduciary doctrine are Chase Manhattan Bank v. Israel-British Bank, [1981] Ch. 105 [hereinafter Chase Manhattan] and Goodbody v. Bank of Montreal (1974), 47 D.L.R. (3d) 335 (Ont. H.C.) [hereinafter Goodbody]. In each of these cases, fiduciary relationships were found to exist by the courts solely to allow for 
misapplied fiduciary law in a variety of instances: for remedial purposes in cases where there has been no demonstrated existence of a fiduciary relationship or where such a demonstration would prove impossible, ${ }^{12}$ and where heads of obligation exist independently of the fiducial relation. ${ }^{13}$

Despite, or perhaps because of, the general confusion surrounding fiduciary doctrine, it has recently experienced a tremendous growth in use. ${ }^{14}$ Fiduciary arguments have become something of a "catch-all" - if all other claims are meritless or no other cause of action exists, a claim of breach of fiduciary duty is often resorted to. ${ }^{15}$ In Burns v. Kelly Peters \& Associates Ltd., Lambert J.A. highlighted the potential problem stemming from the indiscriminate use of fiduciary doctrine's malleable principles in this fashion:

The danger, of course, with such a flexible remedy, is that it should be used as a catch-all for cases which offend against some of the more exacting standards of commercial morality. So the extra flexibility should promote a sense of caution in determining whether the fiduciary relationship exists.

Or, as Viscount Haldane said in Nocton v. Ashburton, at 966: "... the special relationship must ... be clearly shown to exist...." "t6

The increase in the use of fiduciary arguments has not escaped notice by the judiciary. In Girardet v. Crease \& Co., Southin J., as she then was, noted that "[t]he word 'fiduciary' is flung around now as if it applied to all breaches of duty by solicitors, directors of companies and so forth."17 In LAC Minerals Lid. v. International Corona Resources Lid., La Forest J. stated that "[t]here are few legal

the equitable tracing of funds rather than because of the fiduciary nature of the relationship between the parties concerned. These cases will be discussed in greater detail below.

See Reading v. Attorney-General, [1949] 2 K.B. 232 (C.A.), aff'd [1951] A.C. 507 (H.L.) [hereinafter Reading]; Fonthill Lumber Ltd. v. Bank of Montreal (1959), 19 D.L.R. (2d) 618 (Ont. C.A.), where the defendant bank was held liable for a breach of a "transmitted fiduciary obligation" arising from its acceptance of money from one of its customers that was properly the subject of a statutory trust owed by the customer to his creditors; Courtright v. Canadian Pacific Ltd. (1983), 5 D.L.R. (4th) 488 (Ont. H.C.), aff d (1985), 18 D.L.R. (4th) 639 (Ont. C.A.), where a lawyer who failed to disclose his knowledge that he might be charged with a Criminal Code offence to a potential employer and was later arrested and charged after he had been hired by the company as in-house counsel, was held to have breached a fiduciary obligation to the company even though he was later acquitted of the charge.

Such as in the Chase Manhattan and Goodbody decisions, supra note 11, which should have been decided on the basis of unjust enrichment.

See M.V. Ellis, Fiduciary Duties in Canada (Toronto: De Boo, 1988) at 1-8: "It is somewhat ironic that this area - one of the most rapidly expanding and powerful areas of law - is probably one of the least understood."

In fact, one commentator has gone so far as to suggest that the fiduciary argument is one that cvery litigant should consider: see M.D. Talbott, "Restitution Remedies in Contract Cases: Finding a Fiduciary or Confidential Relationship to Gain Remedies" (1959) 20 Ohio St. L.J. 320.

(1987), 41 D.L.R. (4th) 577 (B.C.C.A.) at 599. See also the comments made by Finn, supra note 10 at 10, discussing in particular the fiduciary's duty of disclosure; and more generally ibid. at 24-25: "A compliant judiciary, particularly in some North American jurisdictions, has been prepared on occasion to use the fiduciary principle to provide desired solutions in situations where the law is otherwise deficient or is perceived to be so." 
concepts more frequently invoked but less conceptually certain than that of the fiduciary relationship." ${ }^{\text {18 }}$ Judicial notice of the misapplication of the fiduciary concept illustrates the existence of a serious problem. What have often purported to be applications of fiduciary principles by the courts have too often been an amalgamation of unrelated rules, only some of which may be a part of fiduciary doctrine.

Part of the confusion surrounding fiduciary doctrine may be traced to judicial tendencies to incorrectly view the labeling of a person or relationship as fiduciary as the end of their investigatory process. The judiciary has often acted as though the mere description of a relationship as fiduciary was sufficient to enable it to apply a remedy. ${ }^{19}$ The American jurist Oliver Wendell Holmes once stated that "It is one of the misfortunes of the law that ideas become encysted in phrases and thereafter for a long time cease to provoke further analysis." ${ }^{20}$. Rather than denoting the end of judicial investigation, describing a person or a relationship as fiduciary creates the need for further inquiry. As Mr. Justice Felix Frankfurter explained in Securities \& Exchange Commission v. Chenery Corp.:

[T]o say that a man is a fiduciary only begins analysis; it gives direction to further inquiry. To whom is he a fiduciary? What obligation does he owe as a fiduciary? In what respect has he failed to discharge these obligations? And what are the consequences of his deviation from duty? ${ }^{21}$

The judicial desire to describe relationships as fiduciary cannot ignore the ramifications of such a description en route to the imposition of one of fiduciary doctrine's desirable remedies. ${ }^{22}$ Without knowing what it is that renders a person or relationship fiduciary, that description is meaningless. The explanation of the obligations arising by virtue of the relationship's existence is what breathes life into the fiduciary characterization. This necessitates, however, an investigation into the nature of the interaction giving rise to the fiduciary relation:

It is pointless to describe a person - or for that matter a power - as being fiduciary unless at the same time it is said for the purposes of which particular rules and principles that description is being used. These rules are everything. The description "fiduciary," nothing."

(1989), 61 D.L.R. (4th) 14 (S.C.C.) at 26 [hereinafter LAC Minerals]. See also P.D. Finn, Fiduciary Obligations (Sydney: The Law Book Company, 1977) at 1:

[T] he term "fiduciary" is itself one of the most ill-defined, if not altogether misleading terms in our law. Yet it retains a large currency being often used as though it were full of known meaning and despite judicial warnings to the contrary.

This phenomenon has even occurred without regard for whether a relationship is properly described as fiduciary: see the discussion entitled "The Misapplication of Fiduciary Doctrine," in Part IV, below.

Hyde v. United States, 225 U.S. 347 (1911) at 391.

318 U.S. $80(1943)$ at $85-86$.

The rationale for the imposition of fiduciary remedies will be discussed in Part III, below.

Finn, supra note 18 at 1. 
This article rests upon twin premises: that fiduciary doctrine is both a valuable tool for the control and regulation of socially valuable or necessary relationships and that it has often been wrongfully characterized and misunderstood. ${ }^{24}$ Fiduciary law is not only "law's blunt tool" for the control of a fiduciary's discretion, ${ }^{25}$ but shapes the parameters of a beneficiary's ability to rely upon his or her fiduciary's good faith exercise of that discretion. Fiduciary relationships ought to be understood both for the duties and obligations possessed by fiduciaries as well as the benefits that flow to beneficiaries from the existence of such relationships. This necessitates a contextualization of fiduciary doctrine, something that has been omitted far too frequently from juridical examinations.

This article suggests that there is a need for a different approach to fiduciary doctrine that can avoid the pitfalls that have resulted in its inconsistent application by the judiciary. Such an approach ought to begin by looking to the theoretical basis and origins of fiduciary doctrine for guidance in the proper method of understanding and applying fiduciary principles. After discovering the rationale behind the imposition of fiduciary doctrine, the analysis then looks to existing theories and commentaries to ascertain their key aspects, but also to account for their limitations. What is needed, then, is a explication of the underlying purpose of fiduciary doctrine, what it aims to promote, and how it attempts to do so through an examination of its theoretical underpinnings. Once these are understood, it is possible to apply the principles of fiduciary doctrine in a manner which is consistent with the doctrine's fundamental purpose.

\section{A FUNCTIONAL APPROACH TO FIDUCIARY DOCTRINE}

Traditionally, fiduciary relationships have been defined according to categories. Where questions of the fiduciary nature of particular relationships arose, juridical examinations would focus upon whether the relationship under scrutiny belonged to the list of relationships that were generally understood to be fiduciary in nature, such as trustee and beneficiary, parent and child, and guardian and ward. The nature of the particular relationship itself or the interaction of the parties involved in it was a secondary matter. Accordingly, there were no established guidelines for determining what constituted a fiduciary relationship:

[I]n times gone by we really were not troubled by the absence of a coherent definition. When pushed to answer the question of who a fiduciary is, we simply rattled off the standard categories of fiduciaries: trustee-beneficiary, agent-principle [sic]; director-company; guardian-ward and

While these premises will be discussed in greater detail below, they underlie the assertions made throughout this paper in that they shape and inform the understanding and application of fiduciary doctrine. 
solicitor-client. The traditional approach, in other words, was that although we could not define "the beast," we could recognize one when we saw it so lack of a definition was not a problem."

The use of categories to determine the fiduciary nature of a relationship runs counter to the very basis of fiduciary doctrine. Fiduciary law has its origins in public policy, specifically the desire to protect certain types of relationships that are deemed to be socially valuable or necessary. ${ }^{27}$ The common elements to the relationships which come under its protection are the trust and confidence placed by one person in another within a given context. This reposing of trust by one person in the honesty, integrity, and fidelity of another, as well as the former's reliance upon the latter's care of that trust, is the basis for the creation of legal mechanisms such as fiduciary law and the law of trusts. ${ }^{28}$ These laws seek to protect those who trust in the ability of others from having that trust abused. ${ }^{29}$

The policy underlying the law of fiduciaries is focused upon a desire to preserve and protect the integrity of socially valuable or necessary relationships which arise from human interdependency. Fiduciary law's preservation of relationships that come under its auspices requires that fiduciaries ascribe to a high standard of conduct. This is achieved through the imposition of certain restrictions upon fiduciaries' fulfillment of their special office, a requirement necessitated by virtue of the inherent inequality of the parties created by the nature of their interaction. ${ }^{30}$ Meanwhile, the ever-increasing degree of interdependency in societies governed by English common law or its derivatives has resulted in the commensurately-broadened mandate of fiduciary law within those spheres. Fiduciary doctrine has expanded its application to fill the increasing need to protect those who are dependent upon others for particular tasks and to ensure that relationships created by the push towards interdependency remain viable. Weinrib has suggested that:

A sophisticated industrial and commercial society requires that its members be integrated rather than autonomously self-sufficient, and through the concepts of commercial and property law provides mechanisms of interaction and interdependence. The fiduciary obligation ... constitutes a means by which those mechanisms are protected."

E. Gillese, "Fiduciary Relations and Their Impact on Business and Commerce" (paper presented to the Insight Conference on "Trusts and Fiduciary Relations in Commercial Transactions" 14 April 1988) at 7.

27

As Finn, supra note 10 at 26 explained:

It has been used, and is demonstrably used, to maintain the integrity, credibility and utility of relationships perceived to be of importance in a society. And it is used to protect interests, both personal and economic, which a society is perceived to deem valuable.

See Nocton v. Ashburton, [1914] A.C. 932 (H.L.) at 963, Lord Dunedin: "there was a jurisdiction in equity to keep persons in a fiduciary capacity up to their duty." See also Canson Enterprises Lid. v. Boughton \& Co., supra note 5 at 154, McLachlin J.

See J.C. Shepherd, The Law of Fiduciaries (Toronto: Carswell, 1981) at v: "The law of fiduciaries is the legal system's attempt to recognize the more blatant abuses of the trust we place in each other."

This not to suggest, however, that all fiduciary relationships exist between patently unequal parties. See the discussion of inequality theory, below.

Weinrib, supra note 25 at 11. 
Without individuals' need to rely upon others, there would be no need for fiduciary law. However, while fiduciary law exists because individuals rely upon each other, maintaining the viability of an interdependent society requires that that interdependency is closely monitored to avoid the potential for abuse existing within such relations. Individuals are far more apt to subject themselves to situations of dependence or reliance upon others if they can be assured that their interests and consequent vulnerability created by the relationship ${ }^{32}$ are protected. Fiduciary law satisfies this additional need by providing protection for beneficiaries who are involved in fiduciary relations from the potential for indecorous activities against their interests by unscrupulous fiduciaries. Therefore, the existence of fiduciary law protects the interests of individuals who rely upon others and allows for the continuation and proliferation of interdependent relationships which carry the possibility for mala fide activity by one party against the other.

What is truly important, then, and what fiduciary law is designed to protect, is the integrity of a wide variety of socially-valuable or necessary relationships. ${ }^{33}$ Therefore, fiduciary law ought to be applied on the basis of its inherent purpose rather than through the application of "established" categories of fiduciary relations. Protecting the integrity of these relationships requires that those who possess the ability to affect others' interests be prevented from abusing their powers for personal gain. Since individual beneficiaries or external factors such as existing social mores or the marketplace cannot completely eliminate the potential for fiduciaries to abuse their positions, equity fills this gap through its imposition of fiduciary doctrine. ${ }^{34}$

In addition to augmenting the constraints of social mores and the rules of the marketplace, equity's imposition of fiduciary doctrine also ensures that the spirit, as well as the intent, of interdependent relations is maintained. In McLeod and More v. Sweezey, ${ }^{35}$ the defendant was to stake and record some asbestos mineral claims on behalf of the plaintiffs as part of a profit-sharing agreement. The defendant reported that there was no asbestos, whereupon the plaintiffs allowed the claims that had been staked under the agreement to lapse. When the defendant was no longer associated with the plaintiffs, he returned to the area - which had no asbestos, but which he knew was rich in chrome - and staked his own claims. The plaintiffs brought an action against the defendant for their share of the profit earned from the sale of his claims.

In finding in favour of the plaintiffs, the Supreme Court of Canada imposed a constructive trust upon the proceeds from the defendant's sale of the claims, with 75 percent allocated to the plaintiffs as per the agreement. In determining the nature of the defendant's undertaking pursuant to the agreement, the court held that the defendant's

$3 \quad$ See Shepherd, supra note 29; R. Flannigan, "The Fiduciary Obligation" (1989) 9 Ox. J. Leg. Stud. 285 at 297, 320; Weinrib, supra note 25 at 15; Maddaugh, supra note 10 at 26. 
obligations were not limited to asbestos claims, but covered all minerals found in the area staked out:

They had bargained for his mature judgment and for that not only on the possibility of asbestos. The expression in the memorandum agreement, "asbestos mineral claims," was description [sic] of what had been originally staked. The plaintiffs desired an expert opinion on those claims in the totality of their possibilities and not on one of them only. That, therefore, was the measure of the defendant's duty as the fiduciary of the plaintiffs in acting upon the disclosure of all the plaintiffs had of value; he undertook to apply his experience to everything found in the area of the claims.... He, therefore, owed to the plaintiffs the utmost good faith in his examination of the structure, formation, and other cvidence of the land to which he was directed, and a duty to give them an unreserved account of what he had found and what, in his judgment, the mineral prospect was."

In the McLeod case, the existence of the defendant's fiduciary duties to the plaintiffs prohibited him from being able to take advantage of a technicality - no asbestos, but chrome - for personal gain at the expense of others. Had he not entered into the agreement with the plaintiffs, under which they reposed their trust and confidence in him and gave him key information, the defendant would not have known of the existence of the claims and, consequently, would not have discovered the chrome deposits. Essentially, the defendant's duty of utmost good faith to the plaintiffs entailed an obligation to live up to the spirit of the agreement - i.e. an obligation to report on the existence of all minerals, not just asbestos - and not merely its technical terms. Of course, the defendant's duty in this sense was not unlimited. Had he found the existence of an underground spring or a rare breed of truffle on the claimed lands and kept that information to himself for his own benefit, it is arguable that he would not have been found liable for a breach of fiduciary duty - the information would likely be deemed to be too far removed from his obligation to the plaintiffs for him to have to share it with them. ${ }^{37}$

Two basic themes become evident from the theoretical basis of fiduciary doctrine. Initially, it is apparent that the fiduciary nature of any relationship arises from circumstances peculiar to that relationship and the interaction of its participants and not as a result of belonging to "traditional" categories of fiduciary relations. Secondly, since fiduciary relationships ought not be confined to already established categories and should be determined by a more functional approach, the categories of relationships that may be described as fiduciary should be viewed as open-ended.

3 The spirit of the defendant's undertaking limited him to disclosure of matters relating only to mineral exploration, not anything of value on the lands in question. See also Maddaugh, supra note 10 at 30 , who arrives at similar conclusions. Other cases which turn on similar fact situations as McLeod include Tombill Gold Mines Lid. v. Hamilion (1956), 5 D.L.R. (2d) 561 (S.C.C.) and Pre-Cam Exploration and Development Lid. v. McTavish (1966), 57 D.L.R. (2d) 557 (S.C.C.). 


\section{A. THE SITUATION-SPECIFIC NATURE OF FIDUCIARY DOCTRINE}

The most vital aspect of fiduciary doctrine, and what ought to receive the bulk of juridical attention, is its focus upon the specific characteristics of individual relationships. In its own milieu, the basis of fiduciary theory is quite general and deliberately so. However, to be consistent with its theoretical basis, the facts specific to the relationship being examined must provide the necessary guidelines for the application of fiduciary doctrine's general principles. A priori assessments are therefore completely inappropriate within the realm of fiduciary law. Because of its implementation on a case-by-case basis, fiduciary doctrine is most appropriately described as situation-specific. What this means is that the law of fiduciaries is not properly implemented without regard for the context within which it is to be applied.

The situation-specific nature of fiduciary doctrine renders the judiciary's implementation of fiduciary doctrine a much more proactive endeavour than the application of most legal principles. The tremendous importance of this characteristic is reflected in the notion that a relationship ought to be described as fiduciary only if its nature, as well as the circumstances under which it exists, warrant its classification as fiduciary:

What must be shown ... is that the actual circumstances of a relationship are such that one party is entitled to expect that the other will act in his interests in and for the purposes of the relationship. Ascendancy, influence, vulnerability, trust, confidence or dependence doubtless will be of importance in making this out, but they will be important only to the extent that they evidence a relationship suggesting that entitlement. ${ }^{3 x}$

Since the determination of the fiduciary nature of any relationship is situation-specific, it follows that it is not possible to authoritatively determine the totality of relationships which may be deemed to be fiduciary. ${ }^{39}$ For these reasons, any attempt to create a taxonomic definition of fiduciary relations in the absence of context is impossible or, at the very least, unwise:

Everything depends on the particular facts, and such a relationship has been held to exist in unusual circumstances as between purchaser and vendor, as between great uncle and adult nephew, and in other widely differing sets of circumstances. Moreover, it is neither feasible nor desirable to attempt closely to define the relationship, or its characteristics, or the demarcation line showing the exact transition point where a relationship that does not entail that duty passes into one that does...."

3* Finn, supra note 10 at 46.

3) This accounts for the open-endedness of fiduciary doctrine.

41 Lloyd's Bank v. Bundy, [1975] I Q.B. 326 (C.A.) at 341. Sec also Re Craig, [1971] Ch. 95 at 104. The situation-specificity of fiduciary doctrine was described by Maddaugh, supra note 10 at 30 in relation to ascertaining the scope and intensity of particular fiduciary duties owed in specific situations, in the following manner: "No single test or set of tests will suffice. As in the case of identifying a fiduciary in the first place we must look to the particular relationship that exists between the parties." 
The situation-specific nature of fiduciary doctrine also has a tremendous effect upon the nature of the duties and obligations which fiduciaries may owe to their beneficiaries, the rights and entitlements of the beneficiaries, as well as the application of fiduciary rules to specific relationships. None of these considerations may be determined in the absence of contextual analysis of the particular relationship under scrutiny:

So much varies in the application of fiduciary principles in particular contexts that the conception of fiduciary obligation itself is unable to justify its applicability, as a general matter and irrespective of context. This view, however, does not deny that the concept of fiduciary obligations has content, or that the content is cogent and intelligible; any general theory of fiduciary obligation that ignored this content would lack integrity and persuasiveness."

The situation-specific nature of fiduciary doctrine stresses that fiduciary law should not properly be boiled down into a simplified theory capable of precise and identical application to all relationships. To do so would eliminate the flexibility that is one of fiduciary theory's most valuable attributes. Therefore, while the situation-specific nature of fiduciary doctrine prevents the fiduciary relation from being precisely defined in the absence of context, that does not prohibit a general understanding of fiduciary theory.

Despite fiduciary doctrine's need for contextual analysis, common core principles of fiduciary doctrine are capable of being isolated and scrutinized in the absence of context. Indeed, fiduciary principles cannot be properly implemented unless they are first understood in a general fashion and then given contextual application through their adaptation to individual relationships. After all, without an awareness of the underlying theory upon which fiduciary doctrine is premised and the goals that it seeks to achieve, it is difficult to see how the various aspects of fiduciary theory work together to achieve their objectives when the objectives remain unknown. It should be noted, however, that the application of these principles to various relationships will differ to the same degree as the relationships differ from each other. ${ }^{42}$ Just as not all fiduciary relationships are identical, the application of fiduciary principles to those relationships is not identical. Subsequently, recognizing that fiduciary doctrine is situation-specific ought to be both a primary consideration and a precursor to its application to particular relationships. ${ }^{43}$

\section{B. THE CATEGORICAL OPEN-ENDEDNESS OF FIDUCIARY RELATIONSHIPS}

The open-ended nature of fiduciary doctrine holds that no relationship may be precluded from being classified as fiduciary because it does not fit into established at 910.

$12 \quad$ Sec ibid. at 879; Flannigan, supra note 33 at 311.

43 This notion has been suggested by DeMott, supra note 41 at 879 , where she stated that "[r]ecognition that the law of fiduciary obligation is situation-specific should be the starting point for any further analysis." 
classes of fiduciary relationships or because the actors involved are not traditionally associated with fiduciary relations. ${ }^{44}$ It maintains that the only relevant consideration is whether the nature of the relationship is such that it ought to be considered fiduciary.

While a relationship is fiduciary if it possesses certain characteristics, the limits of fiduciary relations should not be absolutely defined by those characteristics. Strict limitation offends the situation-specificity of fiduciary doctrine. As Sir Eric Sachs J. explained in Lloyd's Bank v. Bundy, "the relationships which result in such a duty must not be circumscribed by reference to defined limits...." ${ }^{15}$ Being mindful of fiduciary law's focus on the unique attributes of individual relationships ought to prevent the creation of exhaustive lists or categories of fiduciary relations that arise at the expense of the underlying purposes for their institution: "[t]he existence of a list of nominate relations dulls the mind's sensitivity to the purposes for which the list has evolved and tempts the court to regard the list as exhaustive and to refuse admittance to new relations which have been created as a matter of business exigency. ${ }^{146}$

Even where particular types of relationships have been described by the courts as fiduciary, that does not necessarily entail that every instance of those relationships is fiduciary. Furthermore, not every aspect of a fiduciary relationship is fiduciary. ${ }^{47}$

See Tate v. Williamson (1866), 2 L.R. Ch. App. 55 (Ch.) at 60-61:

The jurisdiction exercised by Courts of equity over the dealings of persons standing in certain fiduciary relations has always been regarded as one of a most salutary description. The principles applicable to the more familiar relations of this character have been long settled by many well-known decisions, but the Courts have always been careful not to fetter this useful jurisdiction by defining the exacts limits of its exercise.

The open-endedness of fiduciary categorization is well-recognized in Canadian jurisprudence. See e.g. Laskin v. Bache \& Co. (1971), 23 D.L.R. (3d) 385 (Ont. C.A.) at 392; Canadian Aero Service, supra note 3 at 383; Guerin, supra note 6 at 341; International Corona Resources Lid. v. LAC Minerals Lid. (1988), 62 O.R. (2d) I (C.A.) at 44: "The circumstances which give rise to such a relationship have not been fully defined nor are they forever closed"; and ibid. at 46, referring to Dickson J.'s judgment in Guerin, supra note 6 at 341; M.(K.) v. M.(H.), supra note 8 at 326, La Forest J.: "In LAC Minerals I stressed the point, which also emerges from Frame v. Smith, that the substance of the fiduciary obligation in any given case is not derived from some immutable list of duties attached to a category of relationships. In other words, the duty is not determined by analogy with the "established' heads of fiduciary duty." Supra note 40 at 341 . See also Ellis, supra note 14 at 1-7: "It is readily apparent that the Courts will not - indeed, cannot - create an exhaustive list of fiduciary categories"; L.S. Sealy, "Some Principles of Fiduciary Obligation" [1963] Camb. L.J. 119 at 135; Weinrib, supra note 25 at 7; J.R.F. Lehane, "Fiduciaries in a Commercial Context" in P.D. Finn, ed., Essays in Equity (Sydney: The Law Book Company, 1985) at 96; Sir A. Mason, "Themes and Prospects" in Finn, ed., ibid. at 246; Hon. J.R.M. Gautreau, "Demystifying the Fiduciary Mystique" (1989) 68 Can. Bar Rev. 1 at 8.

46 Weinrib, ibid. at 5 .

47 See Shepherd, supra note 29 at 21; Finn, supra note 18 at 4: L.S. Sealy, "Fiduciary Relationships" [1962] Camb. L.J. 69 at 81; R. Flannigan, "Fiduciary Obligation in the Supreme Court" (1990) 54 Sask. L. Rev. 45 at 51; D. Klinck, "'Things of Confidence': Loyalty, Secrecy and Fiduciary Obligation" (1990) 54 Sask. L. Rev. 73 at 87; R.G. Slaght, "Proving a Breach of Fiduciary Duty" in Fiduciary Duties, supra note 10 at 40 : "A relationship may be fiduciary in nature for only some specific purposes or in respect of some specific property, idea or action, or concerning only one of a number of joint undertakings"; New Zealand Netherlands Society 'Oranje' Inc. v. Kuys, [1973] 2 All E.R. 1222 (P.C.) at 1225-26: "A person ... may be in a fiduciary position quoad a part 
Along this same line of reasoning, La Forest J. held in LAC Minerals Ltd. v. International Corona Resources Ltd. that it is far more important to look at the particulars of a relationship to ascertain whether it is fiduciary rather than simply observing who the parties to it are:

The imposition of fiduciary obligations is not limited to those relationships in which a presumption of such an obligation arises. Rather, a fiduciary obligation can arise as a matter of fact out of the specific circumstances of a relationship. As such it can arise between parties in a relationship in which fiduciary obligations would not normally be expected. ${ }^{4 k}$

What is truly meant by the open-endedness of the fiduciary relation, then, is that the categories of fiduciary relations are never closed and neither are their limits.

\section{IMPLEMENTING THE FUNCTIONAL APPROACH}

Whereas the integrity of fiduciary relations may be preserved by prescribing acceptable standards of fiduciaries' conduct, the success of such a regime is ultimately dependent upon a proper balance being struck between the desire to protect beneficiaries' interests and the sanctioning of fiduciaries' behaviour. The fiduciary office will remain vacant if the cost to prospective fiduciaries is so high that they are discouraged from accepting the position. Fiduciary doctrine attempts to provide an equitable balancing of the need to preserve the integrity of fiduciary relations by imposing strict standards of conduct upon fiduciaries which are sufficiently stringent to protect beneficiaries' interests, yet not so strict as to discourage others from accepting the fiduciary office. ${ }^{49}$

Using a functional approach to understanding fiduciary doctrine differs significantly from category-based modes of analysis. It provides a sound theoretical basis for the imposition of fiduciary principles rather than resorting to a list of relationships previously described as fiduciary on some level. However, this type of approach differs from the adherence to categorical analysis in a far more significant way. It insists that fiduciary doctrine should be applied only where its application is consistent with the doctrine's theoretical foundations. Under a functional approach, fiduciary theory provides solid guidelines for determining the application of fiduciary principles to specific relationships as well as parameters for the application of fiduciary principles to relationships at large. Thus, promoting a functional understanding of fiduciary doctrine also requires providing some boundaries for the application of fiduciary doctrine.

of his activities and not quoad other parts: each transaction, or group of transactions, must be looked at"; Mclnerney v. MacDonald, supra note 7 at 423: "A relationship may properly be described as "fiduciary" for some purposes, but not for others." 
Numerous relations between persons within any given society entail some form of dependence or potential for one person to positively or negatively affect the interests of another. These relationships take a variety of forms. Not all of them involve the reposing of trust, however. Moreover, not all of them ought to be treated as fiduciary in nature. The potential for one person's interests to be affected by the actions of another varies in degree according to a number of criteria. These include, among other things, the nature and scope of the relationship and the degree of trust and reliance involved. While the determination of the types of relationships that come under fiduciary law's protective sheath ought to be made according to the facts and requirements of the specific relationship under scrutiny and not be limited by general rules, this does not entail that all relationships involving degrees of dependency, reliance, or trust ought to be characterized as fiduciary.

There are other reasons why fiduciary doctrine ought not to be implemented as freely as it has been in the past. The duties and penalties imposed upon fiduciaries are quite onerous. Fiduciaries must ascribe to high standards of morality and selflessness, as reflected in the concept of utmost good faith, or uberrima fides. Moreover, the wide range of remedies available for breach of fiduciary duty reflect, in part, equity's desire to punish fiduciaries for breach of their duties as well as to discourage other fiduciaries from engaging in acts of breach. Consequently, the application of fiduciary standards of loyalty, disclosure, etc. should not be haphazard, but, as under a functional approach, ought to be based upon a careful consideration of the particulars of the relationship being examined and imposed only where necessary, not simply where their application would provide a convenient resolution to a problematic situation. ${ }^{\text {so }}$ Indeed, in Hodgkinson v. Simms, Sopinka and McLachlin JJ. warned that courts and commentators have used phrases like "unilateral exercise of power," "at the mercy of the other's discretion," and "has given over the power" when describing fiduciary relationships because of their concern for the need to clarify what gives rise to a fiduciary relationship, and, more importantly, because of the "Draconian consequences of the imposition of a fiduciary obligation." 51

The unprincipled application of fiduciary doctrine, whether under the categorical approach or otherwise, may result in the imposition of undeservedly-harsh sanctions upon persons who ought not to be made subject to them. Moreover, it also allows persons who would not otherwise be entitled to fiduciary remedies to be availed of them. Aside from acting as punishments or deterrents for fiduciaries and serving to maintain the integrity of fiduciary relations, fiduciary remedies exist to protect beneficiaries' interests by correcting fiduciaries' abuse of their positions in ways that go beyond ordinary remedies. ${ }^{52}$ Beneficiaries are only entitled to fiduciary remedies by virtue of their positions vis-a- $-v i s$ their fiduciaries and due to fiduciary doctrine's

See the discussion in "The Misapplication of Fiduciary Doctrine," Part IV, below.

Supra note 9 at 219.

Note the comments made by Sopinka and McLachlin JJ. regarding the need to limit the imposition of fiduciary obligations in Hodgkinson, supra note 9 at 217: "The vast disparity between the remedies for negligence and breach of contract - the usual remedies for ill-given advice - and those for breach of fiduciary obligation, impose a duty upon the court to offer clear assistance to those concerned to stay in the former camp and not stray into the latter." 
perception that onerous penalties are required to ensure that fiduciaries live up to the high standards required of them. The reason why parties to a contract, for example, are neither imposed with the same high degrees of loyaity or availed of similarly far-ranging remedial aid is that the moral standards applied to contracting parties is far less exacting than those required of fiduciaries.

The category-based approach used in the past never imposed restrictions upon the scope of fiduciary doctrine's application because it never looked to the basis of fiduciary doctrine's reason for being. While the variety of relationships that are capable of being described as fiduciary are not circumscribed, they are, in fact, limited by the purpose and intent of fiduciary doctrine. Simply put, if a particular relationship is inconsistent with fiduciary doctrine's desire to protect certain forms of interactions, then it is outside of the types of relationships that ought to properly be described as fiduciary.

In general terms, fiduciary law exists to monitor the intercourse between those who give their trust and those who care for that trust. ${ }^{53}$ It ensures that fiduciaries live up to the high expectations required of them, provides beneficiaries with the means to enforce their fiduciaries' duties, and imposes remedies where fiduciaries fail to discharge their obligations. In all, fiduciary law seeks to ensure the equity of dealings between parties to relationships which, by their nature, are particularly susceptible to fraud, undue influence, and other activities which run afoul of public policy. ${ }^{54}$ Unfortunately, as a result of the tremendous scope of activity that fiduciary doctrine was designed to monitor, it has been particularly susceptible to incorrect usage which has hampered its theoretical development.

\section{THE MISAPPLICATION OF FIDUCIARY DOCTRINE}

Despite the complex nature of fiduciary doctrine, the judiciary has avoided serious theoretical analysis of fiduciary doctrine in favour of haphazard and often ill-fitting applications of its most general principles. The judiciary's failure to engage in serious analysis of fiduciary theory has prevented it from recognizing the limits of fiduciary doctrine's application. The judiciary's use of fiduciary doctrine in inappropriate scenarios has, in turn, produced a multitude of decisions which only further confuse the issue of fiduciary law's proper scope of application.

See Finn, supra note 10 at 2: "fiduciary law's concern is to impose standards of acceptable conduct on one party to a relationship for the benefit of the other where the one has a responsibility for the preservation of the other's interests."

s4

See the similar sentiments in Flannigan, supra note 33 at 321-22; Vinter, supra note 2 at 2:

The Court of Chancery has, when the interests of the public generally were concerned ... entertained jurisdiction on grounds of public policy, irrespective of the particular circumstances of the case, to declare void transactions which have taken place under circumstances where, independently of other considerations, from the condition of the parties and the difficulty which must exist of obtaining positive evidence as to the fairness of the transaction, they are particularly open to fraud and undue influence. 
One of the most notorious examples of the misapplication of fiduciary doctrine occurred in Chase Manhattan Bank v. Israel-British Bank..$^{55}$ In that case, the plaintiff had transferred two million dollars to the defendant's account. As a result of a clerical error, a second payment in the same amount was made by the plaintiff to the defendant that same day. Upon discovering its error, the plaintiff gave instructions to stop the second payment, but the instructions were not received in sufficient time to prevent the defendant from receiving the funds. The defendant bank was put into receivership shortly thereafter.

As the plaintiff's money was indistinguishable from the other money belonging to the defendant, it could not be recovered through common law remedies. To trace property at common law, title to the property being followed must be readily identifiable. $^{56}$ The commixture of the plaintiff's funds with those of the defendant prevented identification, and, consequently, the ability to trace. Tracing in equity, however, places a charge upon the asset to be traced, thereby allowing a claimant to follow the asset into a mixed fund or into property purchased with money obtained from such a fund. ${ }^{57}$

In finding for the plaintiff, Goulding J. held that a fiduciary relationship existed between the parties as a result of the incorrect payment of money to the defendant arising from the second transfer. Before the mistaken payment, there had been no existing fiduciary relationship between the parties. Nevertheless, in arriving at his conclusion, Goulding J. determined that to allow for the tracing of the mistakenly-forwarded funds, it was necessary to find "a continuing right of property recognized in equity or of what I think to be its concomitant, 'a fiduciary or quasi-fiduciary relationship." 58 Clearly, the fiduciary relationship found to exist in Chase Manhattan was imposed merely to allow for the equitable remedy of tracing and deny the defendant bank the benefit of the plaintiff's error. The fiduciary relationship was used instead of the more obvious action of unjust enrichment because the latter was not recognized as an independent head of action in England. ${ }^{59}$

A similar judicial "creation" of a fiduciary relationship occurred in Goodbody v. Bank of Montreal, ${ }^{60}$ where the Ontario High Court of Justice declared that the bank of a thief had a fiduciary relationship with the thief's victim to enable the tracing of proceeds from stolen property. A number of a company's share warrants were alleged to have been stolen from the plaintiff's premises. The alleged thief, Lester, claimed to be a bona fide purchaser of the warrants. He claimed to have purchased them from another individual without knowing that they had been stolen. Lester then sold the

Supra note 11.

See D.W.M. Waters, Law of Trusts in Canada, 2d ed. (Toronto: Carswell, 1984) at 1036.

Jbid. at 1037.

Chase Manhaltan, supra note 11 at 119, which was based upon Goulding J.'s adherence to the precedent established in Re Diplock, [1948] Ch. 465, aff d (sub nom. Min. of Health v. Simpson) [1951] A.C. 251 (H.L.).

See Re Diplock, ibid; Reading, supra note 12 at 513-14; Orapko v. Manson Investments Ltd., [1978] A.C. 95 (H.L.) at 104; Waters, supra note 56 at 1045.

Supra note 11. 
warrants, opened a bank account under an assumed name, and deposited the proceeds from the sale of some of the shares in it. Although the court declared that the bank had a fiduciary relationship with the plaintiff, it did not discuss the fiduciary nature of the parties' relationship. Rather, it demonstrated the existence of an unjust enrichment which was deserving of a remedy. As Lacourciere J. explained, "[t]o permit Lester to retain the proceeds of his fraud in such circumstances would be to allow him to benefit from his fraudulent activities, to become unduly enriched at the expense of the plaintiffs." ${ }^{\text {"6I }}$

Once again, the court's inability to use the principle of unjust enrichment resulted in the artificial creation of a fiduciary relationship in order to provide a remedy. The basis of the court's finding of such a relationship was, again, explained by necessity rather than its actual existence: "On the authority of Sinclair v. Brougham et al., [1914] A.C. 398 ... the Court will establish a fiduciary relationship to enable the plaintiffs to follow their property in equity into Lester's bank account."62

Perhaps the prime example of the judicial creation of a fiduciary relationship in an attempt to right an obvious wrong occurred in the case of Reading v. Attorney General..$^{63}$ Reading, a British Army sergeant in Egypt during World War II, assisted smugglers in transporting illicit alcohol by riding in their civilian vehicle in military uniform to avoid inspection by the police. At the time of his arrest, a substantial amount of money in his possession earned from assisting the smugglers was seized. Reading was tried by court-martial, found guilty of conduct prejudicial to good order and military discipline and sent to prison for two years. Upon his release, he commenced an action to have the seized money returned.

In finding that Reading was not entitled to have the seized money returned, the Court of Appeal held that he occupied the position of a fiduciary to the Crown by virtue of his position in the British Army. ${ }^{64}$ The money Reading received from the smugglers was deemed to have constituted a secret profit earned through the breach of his fiduciary duties in favour of his own pecuniary interests. His breach of duty required him to disgorge the amount of his profit to his beneficiary, the Crown ${ }^{65}$ Consequently, he was unable to have the money returned to him, because it properly belonged to his beneficiary. The Court of Appeal's findings were unanimously upheld by the House of Lords. ${ }^{66}$

62 Ibid. at 339. At the time of the Goodbody decision, the judicial recognition of unjust enrichment as an independent cause of action was still in its infancy in Canada: see Deglman v. Guaranty Trust Co. of Canada and Constantineau, [1954] S.C.R. 725. However, the principle of unjust enrichment is now well-recognized following the Supreme Court of Canada's decision in Pettkus v. Becker (1980), 117 D.L.R. (3d) 257 (S.C.C.), thercby climinating the need for the judicial creation of fiduciary relationships to facilitate the equitable remedy of tracing.

Supra note 12.

Ibid.

See the discussion in the section entitled, "Unjust Enrichment Theory," in Part V, below.

Reading v. Attorney General, [1951] A.C. 507 (H.L.). 
Cases such as Chase Manhattan, Goodbody, and Reading illustrate exactly how far courts have been willing to stretch the fiduciary concept in order to find a basis of liability. Although just and equitable results were obtained in each of these cases, the manner in which they were obtained resulted in the extrapolation of fiduciary doctrine far beyond its intended limits. ${ }^{67}$ While it may be arguable that Reading was in breach of his fiduciary obligations by using his uniform for unauthorized and fraudulent purposes, the finding of fiduciary relationships in both the Chase Manhattan and Goodbody cases have no basis in fiduciary doctrine. The latter two cases are the unfortunate products of well-intentioned attempts to provide wronged innocent parties with remedies. However noble the intentions behind such attempts may be, the precedents they created have clouded the perception of fiduciary relationships and the attendant role of fiduciary doctrine therein.

Although the situation-specific nature of fiduciary doctrine presupposes that it possesses sufficient flexibility to be applied to a wide range of relationships, this does not justify its application in situations that are inconsistent with its underlying purpose. Through its unprincipled application by the judiciary, fiduciary doctrine is prone to being imposed in places where it simply does not belong, as evidenced by the illustrations above. Confining fiduciary doctrine to its proper sphere of influence has become increasingly more important in the face of the tremendous increase in the use of fiduciary arguments. The problem is how to prevent its future misapplication. It is suggested that a greater knowledge and awareness of fiduciary theory is needed if fiduciary doctrine is to be kept within its own backyard. This necessitates examining the various fiduciary theories that currently exist.

\section{FIDUCIARY THEORIES}

A number of commentators have attempted to define the fiduciary relation. Some have attempted to define it through taxonomy ${ }^{68}$ Others argue that the fiduciary relation cannot be generally encapsulated, but may be rendered precise by classes for which particular rules may be devised. ${ }^{69}$ There are those who suggest that the fiduciary relation cannot be defined at all. ${ }^{70}$ Still others insist that the fiduciary relationship cannot be delimited because it is an illogical creature created by loosely tied or entirely unrelated principles which have been improperly grouped together for the sake of

Note the commentary by Waters, supra note 56 at 405 , citing the Chase Manhattan and Reading decisions: "It is undeniable that the concept of fiduciary relationship has been stretched in circumstances like these to a degree where it has become meaningless."

See Vinter, supra note 2 at 369: "Certainty of the law is a desideratum, and the reduction of the borderland to as narrow a tract as possible is one of the aims of this book."

Such as Sealy, supra note 47 at 73: "It is obvious that we cannot proceed any further in our search for a general definition of fiduciary relationships. We must define them class by class, and find out the rulc or rules which govern each class" [emphasis in original].

Such as S.M. Beck, "The Quickening of Fiduciary Obligation: Canadian Aero Services v. O'Malley" (1975) 53 Can. Bar Rev. 771 at 781: "Clear definition is simply not possible, or desirable, when one is dealing with the interaction of human conduct and an infinite variety of ... situations." 
the sake of jurisprudential convenience. ${ }^{11}$ Finally, there are those who believe that fiduciary doctrine cannot be understood in the absence of context. ${ }^{72}$

Traditional definitions of the term "fiduciary" have tended to focus upon the similarity of the fiduciary and the trustee and of the fiduciary relationship with the trust relationship. ${ }^{73}$ Indeed, "fiduciary" is derived from the Latin words "fiducia," which means trust, or reliance, and "fiduciarius," which translates to something that is entrusted or given in trust. Moreover, the latter two are derivatives of the verb "fido," which means "to trust. ${ }^{174}$ In the legal context, the notion of fiduciary relations was first conceived of by Equity in relation to trustees, and was later expanded to include the actions of any person who occupies a position of trust or is entrusted by another for a particular purpose. ${ }^{75}$

Both the fiduciary and trust relationship entail similar duties, benefits, and liabilities. The fiduciary relation involves the beneficiary's reposing of trust and confidence in the fiduciary to act in the former's best interests, with the utmost good faith, integrity, candour, and fidelity. The fiduciary is bound, meanwhile, to act selflessly for the benefit of the beneficiary and must not take unfair advantage of the beneficiary so as to prejudice the latter's interests. This basic definition has been refined and expanded over time by judges and legal scholars. Their revisions may be organized into a number of theoretical categories, including property theory, reliance theory, inequality theory, contract theory, unjust enrichment theory, utility theory, and power and discretion theory. ${ }^{76}$

It should be noted at the outset that this list is not meant to include all possible theories of fiduciary doctrine. ${ }^{77}$ Moreover, the following discussions of each of these various theories are not exhaustive. Rather, their inclusion is intended to highlight the various elements that have most often been raised as constituting the basis of fiduciary

See e.g. Finn, supra note 18 at 1; Sealy, supra note 47 at 73; Talbott, supra note 15 at 324.

See DeMott, supra note 41 at 879; Flannigan, supra note 33 at 311 . This paper falls into this category.

See e.g. Black's Law Dictionary, 5th ed. (St. Paul, Minn.: West, 1979) at 563, where the term "fiduciary" is described as being: "derived from the Roman law, and means (as a noun) a person holding the character of a trustee, or a character analogous to that of a trustee..."; see also the Oxford English Dictionary, 2d ed., vol. 5 (Oxford: Clarendon Press, 1989) at 878, where a "fiduciary" is explained as "[o]ne who holds anything in trust: a trustee."

Cassell's Latin Dictionary (New York: Macmillan, 1959) at 247.

See Waters, supra note 56 at 712 .

For the sake of simplicity, the names of the theories used here reflect their major points of emphasis. They are adapted from the examples used by Shepherd, supra note 29 at 51-91.

In practice, many judges and scholars subscribe to a combination of one or more of these theories or their derivatives in formulating their own theories of fiduciary doctrine. However, given the varicty of characterizations of fiduciary doctrine, no single one of these theories is wholly agreed upon or perceived to be better than others; each is the subject of debate or contention on one or more points. See the remark made by Finn, supra note 10 at 26: "Our present uncertainty is thought to be exacerbated by the lack of a workable and unexceptionable definition of a fiduciary. We have no shortage of rival approaches, but none has carried the day." See also Flannigan, supra note 33 at 321: "There have been a number of attempts by commentators recently to explain the basis of the fiduciary obligation.... Unfortunately, there is no consensus." 
relations. From these considerations, the core elements of fiduciary doctrine may be ascertained by the theories' commentaries upon the doctrine's most vital elements.

\section{A. PROPERTY THEORY}

The essential proposition underlying the property theory of fiduciary doctrine holds that a fiduciary relationship exists only where a person possesses de $\mathrm{facto}^{78}$ or de $j^{j u r e}{ }^{79}$ control over property belonging to another. Consequently, where no property interest - in the traditional common law understanding - exists, there can be no fiduciary relationship. Property theory is the starting point of most economic analyses of fiduciary doctrine. Cooter and Freedman, for example, describe a fiduciary relation as existing in any situation where "a beneficiary entrusts a fiduciary with control and management of an asset." ${ }^{80}$ Property theory has also been used in the Native law context to describe the Crown's fiduciary obligation to First Nations. ${ }^{81}$

This theory of fiduciary doctrine may be seen to have its origins in trust law, where the existence of a trust corpus, or res, is a prerequisite for the existence of a trust relationship. However, while the finding of a trust relationship results in the existence of fiduciary duties, it is not the same thing as a fiduciary relationship. A trustee is a type of fiduciary, but a fiduciary is not necessarily a trustee.

In simple terms, a trust creates a legally-binding obligation in which the party or parties controlling the property of the trust - the trustees - hold that property for the benefit of a party or parties - the beneficiaries or cestuis que trust - and not for

De facto control may be obtained by virtue of one person's ability to control property whose legal and equitable title belongs to another. Directors of corporations fall under this category by virtue of being able to control a corporation's assets without owning them.

De jure control may be obtained in any situation where a person has been assigned legal title or legal control over property whose equitable title remains in another. For example, any trustee who holds property in trust for the benefit of another exercises de jure control over that property as long as it remains subject to the trust.

Supra note 10 at 1046. Other "Law and Economics" perspectives on fiduciary doctrine include W. Bishop \& D.D. Prentice, "Some Legal and Economic Aspects of Fiduciary Remuneration" (1983) 46 Mod. L. Rev. 289; K.B. Davis, Jr., "Judicial Review of Fiduciary Decisionmaking - Some Theoretical Perspectives" (1985-86) 80 Nw. U.L. Rev. 1; H.N. Butler \& L.E. Ribstein, "Opting Out of Fiduciary Duties: A Response to the Anti-Contractarians" (1990) 65 Wash. L. Rev. 1; B.R. Cheffins, "Law, Economics and Morality: Contracting Out of Corporate Law Fiduciary Duties" (1991) 19 Can. Bus. L.J. 28; F.H. Easterbrook \& D.R. Fischel, "Contract and Fiduciary Duty" (1993) 36 J. Law \& Econ. 425.

See e.g. R.H. Bartleth, "The Fiduciary Obligation of the Crown to the Indians" (1989) 53 Sask. L. Rev. 301 at 301: "This paper is founded on the thesis that the exercise of discretion or power over property, above and beyond that to which people are usually subject, leads to accountability at law" [emphasis added]. For further discussion of the application of fiduciary doctrine to the relationship between the Crown and First Nations in Canada, see L.I. Rotman, Parallel Paths: Fiduciary Doctrine and the Crown-Native Relationship in Canada (Toronto: University of Toronto Press, 1996); L. Rotman, "Provincial Fiduciary Obligations to First Nations: Nexus Between Governmental Power and Responsibility" (1994) 32 Osgoode Hall L.J. 735; M.J. Bryant, "Crown-Aboriginal Relationships in Canada: The Phantom of Fiduciary Law" (1993) 27 U.B.C.L. Rev. 19. 
themselves in their roles as trustees. ${ }^{82}$ The actors in a fiduciary relationship - the fiduciary and beneficiary/cestui que trust - are governed by virtually identical principles as those governing trust relationships. However, a fiduciary relationship does not depend upon the presence of a property interest for its sustenance. ${ }^{83}$ Its existence depends upon the quality and character of the relationship between parties which gives rise to equitable obligations.

Many fiduciary relationships exist which do not have a property component to them, or at least not a property interest in the traditional legal sense. Indeed, La Forest J. noted in Canson Enterprises Ltd. v. Boughton \& Co. that "[t]here is a sharp divide between a situation where a person has control of property which in the view of the court belongs to another, and one where a person is under a fiduciary duty to perform an obligation where equity's concern is simply that the duty be performed honestly and in accordance with the undertaking the fiduciary has taken on...." ${ }^{184}$ Perhaps the prime examples of relationships which are understood to be fiduciary in nature, yet do not possess a property component are those between a doctor and patient or between a religious leader and a congregation member. While both the health of the patient and the spiritual well-being of the congregation member may loosely be defined as "property" - insofar as they are possessions which belong to a person - they are not "property" as it is traditionally defined by the common law. Nevertheless, this fact has not prevented these relationships from being classified as fiduciary ${ }^{85}$ The fundamental

82 A trust may have one or more trustees and one or more beneficiaries. There is nothing to prevent trustees from also being beneficiaries of the trusts that they administer. In addition, a trustee may hold the property of a trust not for any person or persons, but for an object permitted by law, such as a charitable purpose.

8. See e.g. Moore v. Royal Trust Co., [1956] S.C.R. 880; Standard Investments Ltd. v. C.I.B.C. (1985), 22 D.L.R. (4th) 410 (Ont. C.A.), rev'g (1983), 5 D.L.R. (4th) 452 (Ont. H.C.); Maddaugh, supra note 10 at 17: "A fiduciary relationship is more than a 'trust' relationship, it is a 'trust-like' relationship. The technical difference being there is no requirement that a fiduciary hold legal title to property in the wider context." See also Sealy, supra note 47 at 76; Finn, supra note 10 at 37 :

[I]f a relationship does give one party access to what both parties would reasonably acknowledge to be a thing of value in the circumstances, is there any justifiable reason for allowing the custodian to utilize it disloyally for his own profit and without being accountable therefor, simply because that "thing" does not fall within our conventional conceptions of property?

*4 Supra note 5 at 146 [emphasis in original]. See also Easterbrook \& Fischel, supra note 80 at 435: "Most of the relations on the fiduciary list do not involve management of property, and those that do have substantial differences in both the nature of the duties and the remedies for breach."

ss See Rowe v. Grand Trunk Railway Co. (1866), U.C.C.P. 500; Mitchell v. Homfray (1881), 8 Q.B.D. 587 (C.A.); Williams v. Johnson, [1937] 4 All E.R. 34 (P.C.); Mclnerney v. MacDonald, supra note 7; Norberg v. Wynrib, supra note 7; Ellis, supra note 14 at 10-22; Vinter, supra note 2 at $77-85$ [doctors/medical advisors - patients]; Huguenin v. Baseley (1807), 33 E.R. 526 (Ch.); Parfit v. Lawless (1872), 2 L.R. P. \& D. 462; Allcard v. Skinner (1887), [1886-90] All E.R. Rep. 90 (C.A.); Morley v. Loughnan, [1893] I Ch. 736; Vinter, supra note 2 at 16-29 [religious advisers - followers]. 
problem inherent in the property theory of fiduciary doctrine, then, is that its emphasis upon the property component of a fiduciary relationship is misplaced. ${ }^{86}$

\section{B. RELIANCE THEORY}

The reliance theory of fiduciary doctrine is the most straightforward of the various theories. It is also the most often-used theory, both on its own and in conjunction with elements of others. ${ }^{87}$ Reliance theory insists that a relationship is fiduciary where one person reposes trust and confidence in another. It has been held to apply in relationships as diverse as those between an investor and a stockbroker ${ }^{88}$ or promoter, ${ }^{89}$ between doctor and patient, ${ }^{90}$ and between parent and child. ${ }^{91}$ Where one person reposes confidence in another, that person relies upon the other's honesty, integrity, fidelity, and good faith not to breach that confidence. Sir Eric Sachs J. illustrated this notion in Lloyd's Bank v. Bundy, where he stated that many cases in which fiduciary relationships have been found to exist "arise where someone relies on the guidance or advice of another ... and where the person upon whom reliance is placed obtains, or may well obtain, a benefit from the transaction or has some other interest in it being concluded." ${ }^{.92}$

Under this theory, it is the entrustor's reliance upon the entrustee that provides the impetus for fiduciary doctrine to ensure that the former's reliance is not abused: "Broadly, it may be said that a fiduciary relationship exists, giving rise to obligations of that character, where the relationship is one of confidence, in which equity imposes duties upon the person in whom confidence is reposed in order to prevent the abuse of

See e.g. the comments made by the Hon. B.M. McLachlin, "The Place of Equity and Equitable Doctrines in the Contemporary Common Law World: A Canadian Perspective" in D.W.M. Waters, ed., Equity, Fiduciaries and Trusts, 1993 (Toronto: Carswell, 1993) at 42: "Not only must the first party agree to act on behalf of the other, but the arrangement must have the result of placing the property of the other in the power of the former, thus emulating the classic relationship between trustee and cestui que trust" [emphasis in original]. See also the commentary by T. Frankel, "Fiduciary Relationship in the United States Today" in Waters, ibid. at 178:

1 believe that judges are likely to refuse to extend fiduciary law to new situations when the new situations do not involve property rights. The reason is that historically fiduciary duties were designed to protect property owners. Hence courts develop fiduciary law by drawing an analogy to new relationships ... [from] property relationship[s]; if the new model does not fit, courts are likely to refrain from applying fiduciary law to the new situations. negligent misrepresentation, which are not a part of fiduciary doctrine. For a more detailed discussion of the relationship between fiduciary law and some of these other concepts, see F.A. Reid, The Fiduciary Concept - An Examination of Its Relationship With Breach of Confidence, Negligent Misrepresentation and Good Faith (LL.M. Thesis, Osgoode Hall Law School, 1989); Finn, supra note 8. 
the confidence." ${ }^{93}$ In this sense, reliance theory is theoretically similar both to trust relationships and to so-called traditional definitions of fiduciary relations, such as those existing between parent and child and guardian and ward. ${ }^{94}$

The basis of reliance theory may be seen to be intrinsically morally- or public policy-oriented. Its origins may be traced back to equity's jurisdiction to provide remedies for abuses of trust and confidence reposed by one person in another. ${ }^{95}$ Yet, while reliance is an important facet of a fiduciary relation, many non-fiduciary relationships also contain various degrees of reliance, such as the relations between freely contracting parties. As Waters argues, "not all relationships will be held to be fiduciary, even though they involve reliance upon integrity and the presumption that a party will fully disclose his position." ${ }^{196}$ While reliance may be an element of many fiduciary relationships, its existence is not sufficient, on its own, to warrant labeling a relationship as fiduciary. Reliance, therefore, is more properly viewed as a determinant, rather than determinative, of the fiduciary character of a relationship. ${ }^{97}$

\section{INEQUALITY THEORY ${ }^{98}$}

Inequality theory is premised upon the notion that beneficiaries are generally inferior in power vis-à-vis their fiduciaries. As a result, the theory stresses that fiduciary law functions to temper this inequality by imposing strict duties upon fiduciaries to act in their beneficiaries' best interests. A common illustration of inequality theory's characterization of fiduciary relationships is the relationship between guardian and ward.

Although inequality theory highlights the power imbalance between fiduciaries and beneficiaries within the confines of their fiduciary relationships, it has been improperly expanded beyond those confines. Adherence to this bastardized form of inequality theory has led many to believe that all fiduciary relationships exist only between dominant and subservient parties. This premise is simply untrue. Fiduciary relationships are as prevalent among parties on an equal footing - such as partners in a business venture, spouses, directors of corporations, and partners in professional services firms - as to parties in an unequal relationship - such as employer and employee. While the nature of any given fiduciary relationship may result in an inequality in power

R. Meagher, W. Gummow \& J. Lehane, Equity: Doctrines and Remedies, 2d ed. (Sydney: The Law Book Company, 1984) at 123. See also R.C. Muir, "Duties Arising Outside of the Fiduciary Relationship" (1964) 3 Alta. L. Rev. 359 at 360, who stated that a fiduciary relationship arises "where one party has dominance or influence over another party, which dominance is based upon a confidence reposed in him by that other party." It is also closely related to the inequality theory of fiduciary doctrine, discussed below. See Filmer v. Gott (1774), 4 Bro. P.C. 230 (H.L.); Garlside v. Isherwood (1788), 1 Bro. C.C. 558 (Ch.) at 560; Sealy, supra note 47 at 69-70; DeMott, supra note 41 at 880.

Waters, supra note 56 at 405.

Shepherd, supra note 29 at 58: "Just as there may be a fiduciary relationship without direct reliance, there may be reliance without a fiduciary relationship."

Many of the ideas discussed in this section are discussed in greater detail in L.I. Rotman, "The Vulnerable Position of Fiduciary Doctrine in the Supreme Court of Canada" (1995) 24 Man. L.J. (forthcoming). 
between the fiduciary and the beneficiary within that relationship, there is no requirement or need for any inequality to exist outside of that relationship.

One possible reason for the misunderstanding that an inequality must exist between parties to a fiduciary relationship in all circumstances, including those beyond the fiduciary aspect of their relationship, may be the excessive juridical categorization of acceptable classes of fiduciary relationships. In an unfortunate wave of circularity, many attempts to explain the nebulous fiduciary relation have actually resulted in its perversion. These attempts have not only failed to explain what comprises a fiduciary relation, but have led many to believe that fiduciary relations are restricted to the paradigms established in their illustrations, which tend to be patently unequal relationships. ${ }^{99}$

Indeed, the most common illustrations of fiduciary relationships used by judges and scholars are more akin to those of parent-child, doctor-patient, and employer-employee rather than those between partners in a professional services firm. The Supreme Court of Canada has been a prime culprit in perpetuating the myth that fiduciary relations exist only between unequal parties. ${ }^{100}$ Its recent decision in Hodgkinson ${ }^{101}$ continues the Court's internal debate over the appropriate place of vulnerability as a necessary characteristic of fiduciary relations.

An inherent aspect of fiduciary relationships is that fiduciaries possess the ability, by virtue of their positions, to positively or negatively affect the interests of their beneficiaries. Fiduciary law mandates that the fiduciary's actions adhere to the former; when they result in the latter, the beneficiary has legal recourse to seek appropriate sanctions against the fiduciary. The fiduciary's ability to affect the beneficiary's interests creates a situation of unequal power relations between the two within the confines of that relationship. ${ }^{102}$ However, the power of the parties vis-à-vis each other outside of the boundaries of their fiduciary relationship is irrelevant to the determination of whether any relationship is fiduciary:

See e.g. McTague J.A.'s explanation of what constitutes a fiduciary relationship in Follis v. Albemarle Tp., [1941] 1 D.L.R. 178 (Ont. C.A.) at 181-82:

It seems to me ... there must be established some inequality of footing between the parties, either arising out of a particular relationship, as parent and child, guardian and ward, solicitor and client, trustee and cestui que trust, principal and agent, etc., or, on the other hand, that it can be established that dominion was exercised by one person over another, no matter how the particular relationship may be categoried [sic].

A more complete discussion of inequality theory, its effects, and how it has been recently applied by the Supreme Court of Canada may be seen in Rotman, supra note 98. Sopinka J.; Canson Enterprises Ltd. v. Boughton \& Co., supra note 5; Norberg v. Wynrib, supra note 7; M.(K.) v. M.(H.), supra note 8. Note also Flannigan, supra note 47 at 62-63; Hospital Products Lid. v. United States Surgical Corp. (1984), 55 A.L.R. 417 (H.C. Aust.). 
It cannot be the sine qua non of a fiduciary obligation that the parties have disparate bargaining strength. ... [t]he fiduciary relation looks to the relative position of the parties that results from the agreement rather than the relative position that precedes the agreement. ${ }^{103}$

In "The Vulnerable Position of Fiduciary Doctrine in the Supreme Court of Canada," 104 I suggest that the best way to understand the relative positions of the parties in fiduciary relationships is to think of the fiduciary relationship as a transfer of powers from the beneficiary, $B$, to the fiduciary, $F$. The powers transferred by $B$ to $F$ originally belonged to the former and, in fact, still do. $B$ has merely loaned the powers to $F$ within the ambit of their fiduciary relationship; they do not become $F$ s own possession. $F$ is duty-bound to use these powers in the same manner as $B$ would, subject to any constraints $B$ imposes on their use. $F$ may not exceed these imposed limits, otherwise he is liable for breach of duty; the purpose of $F$ 's duty is to act within the parameters established by $B$ through the latter's transfer of powers, not to exceed them. ${ }^{105}$ When the fiduciary relationship is terminated, the powers return to $B$. A similar method of understanding the relative positions of fiduciaries and beneficiaries in fiduciary relationships was espoused by McLachlin J. in the Supreme Court of Canada's decision in Norberg v. Wynrib, where she explained that: "[i]t is as though the fiduciary has taken the power which rightfully belongs to the beneficiary on the condition that the fiduciary exercise the power entrusted exclusively for the good of the beneficiary." 106

The inequality in the relationship between fiduciary and beneficiary results from the transfer of powers from $B$ to $F$. The inequality of this position is illustrated by the change in power relations between $B$ and $F$ within the boundaries of their fiduciary relationship. Originally both had complete and equal powers $-Q$. Upon the transfer of prescribed powers $(P)$ from $B$ to $F$, the fiduciary relationship came into being. However, within that fiduciary relationship, $F$ s powers now amount to $Q+P$, whereas $B$ only possesses $Q-P$, thereby resulting in a power inequality that did not exist prior to the creation of the fiduciary relation. Although the beneficiary's interests are protected by the law of fiduciaries, this protection serves only as a check on the fiduciary's ability to abuse the power transferred from the beneficiary.

Weinrib, supra note 25 at 6 . Refer also to Gautreau, supra note 45 at 5; Frankel, supra note 34 at 810:

It is important to emphasize that the entrustor's vulnerability to abuse of power does not result from an initial inequality of bargaining power between the entrustor and the fiduciary. In no sense are fiduciary relations and the risks they create for the entrustor similar to adhesion contracts or unfair bargains. The relation may expose the entrustor to risk even if he is sophisticated, informed, and able to bargain effectively. Rather, the entrustor's vulnerability stems from the siructure and nature of the fiduciary relation. Supra note 98.

Hence, for example, the federal Crown's breach of fiduciary duty in Guerin, supra note 6, where the Crown's failure to adhere to the conditions imposed by the Musqueam Indian band upon the latter's surrender of reserve lands rendered it liable for a breach of its fiduciary obligations to the band.

Supra note 7 at 501. 


\section{CONTRACT THEORY}

The contract theory of fiduciary doctrine holds that the fiduciary relationship is quasi-contractual, in that one person undertakes to act in the best interests of another. ${ }^{107}$ The beneficiary in this transaction transfers certain powers to the fiduciary in return for the latter's promise of fidelity to the former's best interests. In accordance with this theory, one recent article has argued that a fiduciary relation is nothing more than a contractual relationship with uncommonly high costs of specification and monitoring: "The duty of loyalty replaces detailed contractual terms, and courts flesh out the duty of loyalty by prescribing the actions the parties themselves would have preferred if bargaining were cheap and all promises fully enforced." 108

The use of contract law as an analogy for understanding the fiduciary obligation may be the result of an attempt to attach the nebulous principles which underlie the law of fiduciaries to the more concrete understanding of contract law. However, the analogy has some rather obvious flaws. While a contract necessarily requires an offer and acceptance, a fiduciary relationship may arise in situations entirely devoid of such formalities. For example, a fiduciary relationship may arise by the unilateral actions of a would-be fiduciary, ${ }^{109}$ by voluntary and mutual arrangements, ${ }^{110}$ as a result of the nature of the intercourse between parties, ${ }^{\prime \prime \prime}$ or by its imposition by the courts. Also, while a gratuitous undertaking is unenforceable in contract law, it is enforceable under fiduciary law. ${ }^{12}$ Moreover, a fiduciary relationship may be found to exist where neither party intended to create such a relationship. ${ }^{13}$

See Easterbrook \& Fischel, supra note 80 at 427: "Fiduciary duties are not special duties; they have no moral footing; they are the same sort of obligations, derived and enforced in the same way, as other contractual undertakings."

Ibid. See also Gautreau, supra note 45 at 29 :

There is no difference in principle between contractual duties, duties of care based on the Hedley Byrne principle and fiduciary duties. They all involve the same elements. The difference is only in degree. The reliance and vulnerability in a fiduciary situation is normally greater than in other duty situations. Because of this, the duty on the fiduciary is more profound and the law makes available a range of remedies that go beyond mere damage awards. But in the end, fiduciary duties are nothing more than elevated contractual duties or duties of care.

Finn, supra note 18 at 201: "[T] he undertaking may be officiously assumed without request." See also A.W. Scott, "The Fiduciary Principle" (1949) 37 Calif. L. Rev. 539 at 540 . It should be noted, however, that fiduciary relationships also arise in the absence of any unilateral undertaking by the would-be fiduciary: see $M .(K$.$) v. M.(H.), supra note 8$ at 324 . Such as entering into a contract or other arrangement, or, in the native law context, the signing of a treaty between the Crown and First Nations.

See Huff v. Price (1990), 76 D.L.R. (4th) 138 (B.C.C.A.) at 171, where it was held that in a situation where no previous fiduciary relationship had existed, a fiduciary relation "grew out of particular elements of the way the structure was managed and manipulated."

See Scott, supra note 109 at 540; Sealy, supra note 47 at 76; Frankel, supra note 34 at 820-21; Lyell v. Kennedy (1889), 14 A.C. 437 (H.L.) at 463, Lord MacNaghten: "Nor do I think it can make any difference whether the duty arises from contract or is connected with some previous request, or whether it is self-imposed and undertaken without any authority whatever."

Frankel, supra note 34 at 821 : "The courts will look to whether the arrangement formed by the parties meets the criteria for classification as fiduciary, not whether the parties intended the legal consequences of such a relation." 
In addition to these problems, the methods by which parties are bound to a contract do not at all coincide with the obligations of fiduciaries to their beneficiaries. In the former, the contract or agreement is the centre of judicial attention to determine the adherence or lack thereof to the bargain made between parties. ${ }^{114}$ On the other hand, fiduciary law places greater emphasis upon the relationship of the parties to each other, their respective undertakings, and the degree of reliance by the beneficiary upon the fiduciary. Finally, and perhaps most importantly, contract law monitors the activities of all parties to the contract, whereas fiduciary law regulates fiduciary relations by focusing exclusively upon the actions of fiduciaries.

There are other important differences between theories of contract and fiduciary law. The ideological underpinnings of contract law are closely tied to the morals of the marketplace. Historically, the freedom and sanctity of contract were put forward as self-evident truths, as evidenced by the remarks of Jessel M.R. in Printing \& Numerical Registering Co. v. Sampson:

[i]f there is one thing which more than another public policy requires it is that men of full age and competent understanding shall have the utmost liberty of contracting, and that their contracts when entered into freely and voluntarily shall be held sacred and shall be enforced by Courts of justice."115

While the unfettered notion of freedom of contract may no longer hold the place that it once did, commercial standards of reasonableness and market pressures still play an important role in determining acceptable standards for contracting parties.

Fiduciary law, on the other hand, has always been premised upon principles which are not limited or dictated by the actions of its participants. Moreover, it prescribes acceptable manners of conduct that are based upon a higher moral standard than that of the marketplace. ${ }^{116}$ The basis of the fiduciary standard is the mirror image of contract's reliance upon parties' self-interest. As Cardozo J. explained in Meinhard v. Salmon:

Many forms of conduct permissible in a workaday world for those acting at arm's length, are forbidden to those bound by fiduciary ties. A trustee is held to something stricter than the morals of the marketplace. Not honesty alone, but the punctilio of an honor the most sensitive, is then the standard of behavior. As to this there has developed a tradition that is unbending and inveterate. Uncompromising rigidity had been the attitude of courts of equity when petitioned to undermine the rule of undivided loyalty by the "disintegrating erosion" of particular exceptions.... Only thus has the level of conduct for fiduciaries been kept at a level higher than that trodden by the crowd. ${ }^{117}$

As reflected by the Parol Evidence Rulc, which holds that where a written contract exists it alone comprises the terms of the deal between the parties.

IIS (1875), L.R. 19 Eq. 462 at 465.

116. See Frankel, supra note 34 at 830: "In the world of contract, self-interest is the norm, and restraint must be imposed by others. In contrast, the altruistic posture of fiduciary law requires that once an individual undertakes to act as a fiduciary, he should act to further the interests of another in preference to his own." 
This aspect of fiduciary doctrine is also reflected in La Forest J.'s majority judgment in one of the Supreme Court of Canada's most recent decisions in the fiduciary law area, Hodgkinson." 18

Because of the significant differences between contract and fiduciary principles, it is suggested that the former's usefulness as a tool to aid in understanding fiduciary doctrine is outweighed by the dangers inherent in its use. Consequently, the use of contract principles, even in the limited form of analogy, ought to be abandoned. As Deborah DeMott has suggested, "[r]esorting unreflectively to contract rhetoric is insidiously misleading and provides no rationale for further development of the law of fiduciary obligation.... [E]ven considering the obligation's elusive nature, descriptions drawn exclusively from contract principles are surely mistaken." ${ }^{119}$

\section{E. UNJUST ENRICHMENT THEORY}

Unjust enrichment theory states that fiduciary relationships exist where beneficiaries obtain remedial aid from their fiduciaries when the latter use their powers for their own ends rather than those of their beneficiaries. The unjust enrichment arises where the fiduciaries, who receive powers from their beneficiaries to use in the latter's best interests, obtain personal benefit by using those powers to their own advantage. In such instances, the fiduciaries are in breach of their duties to their beneficiaries and are liable for the amount of their unjust enrichment, or the unjust enrichment of third parties whom they have wrongfully benefited. The foundation of this theory is illustrated by Fry J. in Re West of England and South Wales District Bank, Ex parte Dale and Co.:

What is a fiduciary relationship? It is one in respect of which if a wrong arise, the same remedy exists against the wrong-doer on behalf of the principal as would exist against a trustee on behalf of the cestui que trust. ${ }^{120}$

Unlike the other theories illustrated herein, unjust enrichment theory may be seen to be remedy-driven. It reasons from the remedy to the breach of duty instead of from the breach of duty to the remedy. The remedy is that fiduciaries must disgorge any benefits they receive by virtue of their unjust enrichment; the duty is that fiduciaries must not take advantage of their acquisition of dominance over their beneficiaries or forfeit any proceeds thereby obtained. Unjust enrichment theory does nothing, then, to assist in the determination of whether a particular relationship is fiduciary. Rather, its focus rests upon the finding of a remedy where a fiduciary is unjustly enriched. ${ }^{121}$

Supra note 9 at $181,187$.

DeMott, supra note 41 at $879-80$.

(1879), 11 Ch.D. 772 at 778.

See G. Jones, "Unjust Enrichment and the Fiduciary's Duty of Loyalty" (1968) 84 L.Q. Rev. 472; Sealy, supra note $\mathbf{4 7}$ at 73 , who states that the unjust enrichment theory espoused by Fry J, in Re West of England and South Wales District Bank, Ex parte Dale and Co., supra note 120, "is really not a definition at all: although it describes a common feature, it does not teach us to recognize a fiduciary relationship when we meet one." 
A fundamental problem with unjust enrichment theory, then, is that it is circular in its reasoning. ${ }^{122}$ The duty cannot be defined without reference to the remedy. This creates a logistical problem in that in a workable theory of fiduciary doctrine "one cannot both define the relation by the remedy and use the relation as a triggering device for remedy." 123 The circularity of unjust enrichment theory may be contrasted with reliance theory, for example, where beneficiaries' reliance upon their fiduciaries provides the basis for the fiduciaries' liability. Under reliance theory, fiduciaries' duties are based upon their utmost good faith, integrity, and fidelity to the best interests of their beneficiaries, who rely upon the fulfillment of their fiduciaries' duties. The remedy is derived from the fiduciaries' failure to carry out their obligations in this manner.

A second problem with unjust enrichment theory is that it often treads dangerously close to the jurisdiction possessed by the equitable doctrine of unjust enrichment. ${ }^{124}$ As an independent head of action, unjust enrichment does not necessarily indicate the existence of a fiduciary relationship; it merely indicates that a person has been unjustly enriched at the expense of another. ${ }^{125}$ Because of the ideological proximity of actions based upon fiduciary doctrine and those based upon unjust enrichment, the use of unjust enrichment theory within the ambit of fiduciary doctrine requires careful monitoring so that situations of unjust enrichment which do not give rise to fiduciary relations are kept within their own independent sphere.

In sum, while a fiduciary relationship may result in an unjust enrichment, an unjust enrichment does not create a fiduciary relationship. Therefore, while unjust enrichment theory is a useful determinant in ascertaining whether a particular relationship is fiduciary, it, like reliance theory, is illustrative rather than indicative of the existence of fiduciary relations.

See also Fischel \& Easterbrook, supra note 80 at 435 , where they state that not only is unjust enrichment theory "perfectly circular," but that "[t]he description can fit any rule while predicting no outcomes."

Weinrib, supra note 25 at 5 .

Gautreau, supra note 45 at 5-6: "Too often we have permitted the fiduciary concept to drift from its conceptual moorings and to become mixed up with the unjust enrichment concept when the two are really quite distinct." See also the discussion of the Chase Manhattan, Goodbody, and Reading decisions, above. Cases in which the concept of unjust enrichment is more appropriately applied include: Fibrosa Spolka Akcyjna v. Fairbairn Lawson Combe Barbour Ltd., [1943] A.C. 32 (H.L.); Deglman v. Guaranty Trust Co. of Canada and Constantineau, supra note 62; Pellkus v. Becker, supra note 62; Sorochan v. Sorochan (1986), 29 D.L.R. (4th) I (S.C.C.); Hunter Engineering Co. v. Syncrude Canada Lid. (1989), 57 D.L.R. (4th) 321 (S.C.C.); Rawluk v. Rawluk (1990), 65 D.L.R. (4th) 161 (S.C.C.) and; Peter v. Beblow (1993), 101 D.L.R. (4th) 621 (S.C.C.).

Note the comments by DeMott, supra note 41 at 913 : "Unjust enrichment is undoubtedly a useful concept in many situations that raise perplexing questions of fiduciary obligation.... But the principle of unjust enrichment cannot explain as a general matter why some people are under the fiduciary constraint and others are not...." 


\section{F. UTILITY THEORY}

The basis of utility theory is closely related to the underlying purpose of fiduciary law. ${ }^{126}$ It holds that fiduciary relationships will be found by the courts in situations where there is a determined need to protect the integrity of particular types of relationships. This may arise in a number of situations, whether because of the relative status of the parties, such as in the relationship between guardian and ward, or because of a perceived commercial utility, such as where directors or employees seize corporate opportunities for themselves. ${ }^{127}$ In other words, the "utility" of the relationship to society at large is what renders it sufficiently important to warrant its placement under the protective auspices of fiduciary doctrine.

The application of utility theory is widespread. It covers the entire range of relationships which may be deemed to be fiduciary: from the public relationship between elected officials and their constituents ${ }^{128}$ to the private relationship between doctor and patient. ${ }^{129}$ The primary drawback to this theory is that it is particularly susceptible to incorrect usage. More specifically, utility theory may be improperly applied to all socially valuable relationships, whether or not they are fiduciary in nature. For utility theory to be a useful aid in determining what relationships are fiduciary, it cannot overstep its boundaries. While some socially valuable relationships are, indeed, fiduciary, the fact that a relationship is socially useful does not necessarily render it fiduciary.

\section{G. POWER AND DISCRETION THEORY}

There are many similarities between power and discretion theory, reliance theory, and inequality theory. Essentially, power and discretion theory holds that a fiduciary relationship exists where one person possesses power and discretion over the interests of another: "the fiduciary obligation is a device that enables the law to respond to a range of situations in which, for a variety of reasons, one person's discretion ought to be controlled because of characteristics of that person's relationship with another." 130 Another formulation of power and discretion theory holds that the fiduciary:

is likely to either have stewardship of some of the assets of the person to whom the duty is owed or will hold an office in which there are uniquely-available opportunities for self-interested activity or,

See the discussion above.

See e.g. Canada Safeway Ltd. v. Thompson, [1952] 2 D.L.R. 591 (B.C.S.C.); Pre-Cam Exploration and Development Ltd. v. McTavish, supra note 37; Canadian Aero Services Ltd., supra note 3. See Bowes v. Toronto (City of (1858), 14 E.R. 770 (P.C.); Edmonton (City of) v. Hawrelak, [1972] 2 W.W.R. 561 (Alta S.C.), aff'd [1973] I W.W.R. 179 (Alta C.A.); rev'd [1976] I S.C.R. 387; Carlsen v. Gerlach (1979), 3 E.T.R. 231 (Alta. Dist. Ct.); J. Locke, Two Treatises of Government, P. Laslett, ed., 2d ed. (Cambridge: Cambridge University Press, 1967) at 385, 399-400; E.M. Rogers \& S.B. Young, "Public Office as a Public Trust: A Suggestion that Impeachment for High Crimes and Misdeameanors Implies a Fiduciary Standard" (1974) 63 Geo. L.J. 1025; Municipal Conflict of Interest Act, R.S.O. 1990, c. M-50.

See the discussion in "The Categorical Open-Endedness of Fiduciary Doctrine" in Part IIB, above. DeMott, supra note 41 at 915 . 
the relationship is likely to be one in which the fiduciary has considerable authority or influence over the individual to whom the duty is owed."'

Like many of the other theories discussed herein, power and discretion theory is closely related to its counterparts. It is, for example, the theoretical complement of reliance theory. Where reliance theory puts emphasis upon the beneficiary's reliance upon the fiduciary's power and discretion, power and discretion theory emphasizes the fiduciary's exercise of power and discretion on which the beneficiary relies. Power and discretion theory also underlines the inequality of the relationship between fiduciary and beneficiary. ${ }^{132}$ In addition, the power and discretion basis of the theory may exist within the realm of property theory - such as through the power and discretion of the fiduciary over property belonging to the beneficiary — or it may be completely devoid of any relationship to property interests.

While one person's power and discretion over another's interests is necessarily a part of fiduciary relationships, power and discretion theory overstates the case. Clearly, not all relationships where one person possesses power and discretion over the interests of another may be properly characterized as fiduciary. For example, a judge possesses power and discretion over civil litigants and criminally accused persons, but the judge's position vis-à-vis those parties does not entail the existence of fiduciary obligations to act in their best interests.

\section{H. SUMMARY}

What may be drawn from the above discussion of the various theories of fiduciary doctrine is that no single one, in and of itself, provides a satisfactory basis for understanding fiduciary doctrine. Indeed, not one of these theories is adequate to the task of addressing all of the multifarious relationships that ought to properly be considered as fiduciary. The various theories of fiduciary doctrine discussed provide different points of emphasis for the determination of whether a relationship ought to be described as fiduciary. However, even in situations where their respective criteria are satisfied, that fact does not necessarily indicate that a relationship is fiduciary, as Finn explains:

It is obviously not enough that one is in an ascendant position over another: such is the invariable prerequisite for the unconscionability principle. It is obviously not enough that one has the practical capacity to influence the other: representations are made, information is supplied (or not supplied) as of course with the object of, and in fact, influencing a host of contractual dealings. It is obviously not enough that the other party is in a position of vulnerability: such is the almost inevitable state in greater or lesser degree of all parties in contractual relationships. It is obviously not enough that some degree of trust and confidence are there: these are commonly placed in the skill, integrity, fairness and also Weinrib, supra note 25; H. Brown, "Franchising - A Fiduciary Relationship" (1971) 49 Tex. L. Rev. 650 at 664. 
honesty of the other party in contractual dealings. It is obviously not enough that there is a dependence by one party upon the other: as the good faith cases illustrate, a party's information needs can occasion this. Indeed elements of all of the above may be present in a dealing - and consumer transactions can illustrate this - without a relationship being in any way fiduciary. ${ }^{13}$

\section{CONCLUSION}

The primary difficulty with existing fiduciary theories is that they are all subject to exception and qualification. A workable theory of fiduciary doctrine ought to be capable of application to all relationships which may be properly described as fiduciary. Accordingly, it must be flexible enough to provide feasible and practical guidelines, yet simultaneously allow for the situation-specificity required by fiduciary doctrine. It must also be consistent with the fundamental premises upon which fiduciary doctrine is based.

The Chase Manhattan, Goodbody, and Reading cases demonstrate how the judiciary has strayed from the boundaries within which fiduciary law was intended to operate. Not all relationships in society are fiduciary relationships. ${ }^{134}$ Accordingly, relations which are not fiduciary in nature ought not to be labeled as fiduciary merely to enable the application of a remedy to a wronged party. Any theory of fiduciary doctrine must recognize this fact in order to avoid the wrongful misapplication of fiduciary doctrine that has plagued judges and theorists alike.

Fiduciary doctrine is a vital element of law. It enjoys widespread application and has the potential to expand even further as the understanding of its theoretical basis and inherent purpose continues to evolve. However, rather than attempting to illustrate specific examples in which fiduciary doctrine has been held to apply, this paper has adopted a functional approach which is based upon an adherence to the purpose and intent of fiduciary doctrine. By examining various theoretical frameworks of fiduciary law and discarding their non-essential elements, it has attempted to extract the principles which comprise the foundation of fiduciary theory and use them as the basis of a more unified approach to fiduciary relationships. Fiduciary doctrine is not merely a set of loosely-fitting or entirely unrelated rules functioning in an ad hoc fashion. Rather, it is a blueprint for the protection and continued efficacy of interdependent societal relations.

By animating the theory of fiduciary relations through an examination of the nexus between the rights and obligations arising under their auspices, the interrelationship between the fundamental characteristics and rules of fiduciary doctrine may be seen in their proper context. It is only when fiduciary law is truly understood that it may escape from the confusion that presently surrounds it. Fiduciary doctrine is not, as one developing a separate body of fiduciary law is that our society is evolving into one based predominantly on fiduciary relations." See also $\mathrm{ibid}$. at 802 : "I submit that we are witnessing the emergence of a society predominantly based on fiduciary relations." 
commentator described it, "a concept in search of a principle." ${ }^{135}$ Rather, it is a vibrant and exciting facet of law whose potential is only beginning to be tapped. It is more accurately described, then, as a concept in need of understanding. 